Tennyson and Mid-Victorian

Publishing 
Jim Cheshire

\section{Tennyson \\ and Mid-Victorian Publishing}

Moxon, Poetry, Commerce 
Jim Cheshire

Lincoln, United Kingdom

ISBN 978-1-137-33814-3

DOI $10.1057 / 978-1-137-33815-0$

ISBN 978-1-137-33815-0 (eBook)

Library of Congress Control Number: 2016950443

(C) The Editor(s) (if applicable) and The Author(s) 2016

The author(s) has/have asserted their right(s) to be identified as the author(s) of this work in accordance with the Copyright, Designs and Patents Act 1988.

This work is subject to copyright. All rights are solely and exclusively licensed by the Publisher, whether the whole or part of the material is concerned, specifically the rights of translation, reprinting, reuse of illustrations, recitation, broadcasting, reproduction on microfilms or in any other physical way, and transmission or information storage and retrieval, electronic adaptation, computer software, or by similar or dissimilar methodology now known or hereafter developed.

The use of general descriptive names, registered names, trademarks, service marks, etc. in this publication does not imply, even in the absence of a specific statement, that such names are exempt from the relevant protective laws and regulations and therefore free for general use. The publisher, the authors and the editors are safe to assume that the advice and information in this book are believed to be true and accurate at the date of publication. Neither the publisher nor the authors or the editors give a warranty, express or implied, with respect to the material contained herein or for any errors or omissions that may have been made.

Cover illustration: (C) Courtesy of Tennyson Research Centre, Lincolnshire County Council

Printed on acid-free paper

This Palgrave Macmillan imprint is published by Springer Nature

The registered company is Macmillan Publishers Ltd.

The registered company address is: The Campus, 4 Crinan Street, London, N1 9XW, United Kingdom 


\section{ACKNOWLEDGEMENTS}

This book is the product of a series of collaborations and I would like to offer my thanks to a number of individuals, institutions and groups.

Anyone who reads this book will notice the heavy debt to the archival materials in the Tennyson Research Centre in Lincoln, owned by Lincolnshire County Council. I have been working on various projects in the archive for the last nine years and have benefitted greatly from the continuous support of Grace Timmins. The development of the catalogue has been a great help to me and Rosalind Boyce's work on Tennyson's letters and other material has made my task much easier. I am very grateful to Lincolnshire County Council for allowing me to quote documents and illustrate visual material from the archive. Recently, I have had the pleasure of teaching MA classes within the archive, which has produced stimulating thoughts and discussions, as has detailed discussion of these materials with John Francis Davies, Amy Culley and Hanna Field.

Other archival deposits have played an important role. I am grateful to the Wordsworth Trust for allowing me to quote from their archival materials and to the British Library for the use of an image and the use of their collections. Sharing knowledge with other Tennyson scholars has helped me to develop my understanding and I would like to thank Ann Kennedy Smith, Juan Miguel Zarandona, Aidan Day, Valerie Purton, Sibylle Erle, Phyllis Weliver, Ewan Jones and Patrick Scott.

The College of Arts and the School of History and Heritage at the University of Lincoln have supported me with research time and travel expenses and my colleagues in the Nineteenth-Century Research Group have taken part in stimulating discussions around my work and many other 
subjects. I would like to thank my colleagues in the conservation subject area for providing me with expertise and equipment, advice, cameras and microscopes that have helped me to examine objects in detail.

Palgrave Macmillan have been very supportive and I would like to thank them for their faith in the value of this book. Tomas René has been consistently prompt and accurate in his response to my queries. I am grateful to West Virginia University Press and Oak Knoll Books for allowing me to reuse sections of earlier publications in Chaps. 5 and 6.

Writing a book such as this has necessitated putting in long hours, which has demanded patience from members of my family, including my parents and my son. In particular I would like to offer special thanks to my wife Isobel. She has borne the brunt of my preoccupation with this project, aided me directly by reading draft chapters and provided me with constant support and encouragement. 


\section{Contents}

1 Introduction: Poetry, Books, and Publishing History I

2 Edward Moxon in Context 25

3 Tennyson by Numbers: Edward Moxon and the Business of Publishing

4 Publishing Tennyson in America 101

5 Moxon, Tennyson and the Illustrated Book 137

6 James Bertrand Payne and the Demise of the Moxon Firm 159

7 Fame and its Consequences 197

8 Conclusion: Tennyson and the Evolution of Victorian Publishing

Select Bibliography

Index 


\section{List of Figures}

Fig. 2.1 J. M. W. Turner, 'Venice' from Samuel Rogers Italy (London: Caddell \& Moxon, 1830), TRC/AT/1894. (C) Tennyson Research Centre and Lincolnshire County Council

Fig. 2.2 Frontispiece to The Poetical Works of Coleridge, Shelley, and Keats (Paris: Galignani, 1829), TRC/AT/773.

(C) Tennyson Research Centre and Lincolnshire County Council

Fig. 3.1 Print runs of Moxon's editions of Tennyson's 1842 Poems, $1842-1855$

Fig. 3.2 Rate of sale of Moxon's editions of Tennyson's 1842 Poems, $1842-1855$

Fig. 3.3 Spines of Moxon's third and fifth editions of Tennyson's 1842 Poems, published 1845 and 1848. (c) Tennyson Research Centre and Lincolnshire County Council

Fig. 3.4 Detail of cloth cover to The Princess (London: Moxon, 1847), showing the same pattern used for the fourth edition of the 1842 Poems, TRC/W/4226. C Tennyson Research Centre and Lincolnshire County Council

Fig. 3.5 Cloth cover to Mand and other Poems (London: Moxon, 1855), the pattern subsequently adopted for all Tennyson's books

Fig. 3.6 Rate of sale of Moxon's editions of The Princess, $1847-1856$

Fig. 3.7 Rate of sale of Moxon's editions of In Memoriam, $1851-1854$

Fig. 3.8 Yearly Sales of Moxon's books of Tennyson's Poetry $1842-1856$ 
Fig. 3.9 Estimated Sales of Idylls of the King and A Selection from the Works of Alfred Tennyson, 1859-1864

Fig. 4.1 Cover to Poems by Alfred Tennyson (Boston: Ticknor and Fields, 1855)

Fig. 4.2 Spine to Poems by Alfred Tennyson, a new edition, enlarged (Boston: William D. Ticknor \& Company, 1849) TRC/W/ 4346. (C) Tennyson Research Centre and Lincolnshire County Council

Fig. 4.3 Cover to The Poetical Works of Alfred Tennyson (Boston: Ticknor and Fields, 1858) - the 'Blue and Gold' edition

Fig. $5.1 \quad$ B. R. Haydon 'Buonaparte' engraved by J. Brain in The Book of Gems. The Modern Poets and Artists of Great Britain ed. by S. C. Hall (London: Whitaker, 1838), TRC/BC/5422.

(C) Tennyson Research Centre and Lincolnshire County Council

Fig. 5.2 S. C. Lees, 'Forgive me/I waste my heart in signs: let be' from Illustrations to Alfred Tennyson's Poem The Princess by Mrs S. C. Lees (London: Dickinson Bros, c. 1850), TRC/W/4355. (C) Tennyson Research Centre and Lincolnshire County Council

Fig. 5.3 T. Dalziel, 'Conclusion' to 'The May Queen' published in The Poets of the Nineteenth Century ed. by R. A. Willmott (London: Routledge, 1858)

Fig. 5.4 Clarkson Stanfield, 'Ulysses', engraved by W. J. Linton and published in Poems by Alfred Tennyson D. C. L. Poet Laureate (London: Moxon, 1857), TRC/W. (C) Tennyson Research Centre and Lincolnshire County Council

Fig. 6.1 James Bertrand Payne's monogram, verso of title page to A Selection from the Works of Alfred Tennyson (London: Moxon, 1865)

Fig. 6.2 John Leighton, cover to A Selection from the Works of Alfred Tennyson (London: Moxon, 1865)

Fig. 6.3 'A List of Books Published by Messrs Edward Moxon \& Co., Dover Street' (London: Moxon, December 1865).

(C) Tennyson Research Centre and Lincolnshire County Council

Fig. 6.4 Arthur Hughes, cover to Enoch Arden with Illustrations by Arthur Hughes (London: Moxon, 1866). TRC/W.

(C) Tennyson Research Centre and Lincolnshire County Council 
Fig. 6.5 Gustave Doré, 'Vivien and Merlin Repose', tipped in albumen print of Doré's drawing from Vivien, illustrated by Gustave Doré (London: Edward Moxon, 1867) TRC/W. (C) Tennyson Research Centre and Lincolnshire County Council

Fig. 6.6 Gustave Doré, 'King Arthur Discovering the Skeletons of the Brothers' lithograph from The Story of Elaine Illustrated in Facsimile from Drawings by Gustave Doré (London: E. Moxon, Son \& Co., 1871). TRC/W.

(C) Tennyson Research Centre and Lincolnshire County Council

Fig. 6.7 Gustave Doré, 'King Arthur Reading the Letter of Elaine', engraving from Elaine, illustrated by Gustave Doré (London: Edward Moxon, 1867) TRC/W. (C) Tennyson Research Centre and Lincolnshire County Council

Fig. 7.1 Samuel Laurence, 'Alfred Tennyson', frontispiece to The Poetical Works of Alfred Tennyson

(Boston: Ticknor and Fields, 1858)

Fig. 7.2 Thomas Woolner, frontispiece to Poems by Alfred Tennyson D. C. L. Poet Laureate (London: Moxon, 1857). TRC/W.

(C) Tennyson Research Centre and Lincolnshire County Council

Fig. 7.3 Thomas Wooler, 'Alfred Tennyson', 1857, from a late nineteenth-century photograph of the marble bust, TRC/IMAGES/6230. (C) Tennyson Research Centre and Lincolnshire County Council

Fig. 7.4 James Mudd, 'Alfred Tennyson', albumen print c. 1857

Fig. 7.5 Frontispiece to A Selection from the Works of Alfred Tennyson (London: Moxon, 1865) - an engraving from a photograph taken by the London Stereoscopic Company

Fig. 7.6 Thomas Woolner, frontispiece to Enoch Arden with Illustrations by Arthur Hughes (London: Moxon, 1866), TRC/W. (C) Tennyson Research Centre and Lincolnshire County Council

Fig. 7.7 Gustave Doré, frontispiece to Idylls of the King. Tennyson Dore (London: Moxon, 1868) TRC/W. (C) Tennyson Research Centre and Lincolnshire County Council

Fig. 7.8 J. E. Mayall, 'Alfred Tennyson D. C. L.', albumen print, from Mayall's New Series of Photographic Portraits of Emminent and Illustrious Persons (London: A. Marion, Son and Co. c. 1864), TRC/IMAGES/5987. (C) Tennyson Research Centre and Lincolnshire County Council 
Fig. 7.9 Charles William Sherborn, 'James Bertrand Payne' c. 1867, steel plate engraving, (C) The British Library Board, AC.8141 (vi), frontispiece

Fig. 7.10 Illustration from title page of Thomas Hood illustrated by Gustave Doré (London: E. Moxon, Son and Co., 1870)

Fig. 7.11 William Jeffery, frontispiece to D. Baron Brightwell, $A$ Concordance to the Entire Works of Alfred Tennyson (London: Moxon, 1869). TRC/BC/4390. C Tennyson Research Centre and Lincolnshire County Council

Fig. 7.12 William Jeffrey, 'Alfred Tennyson', albumen print, TRC/IMAGES/6364. (C) Tennyson Research Centre and Lincolnshire County Council

Fig. 7.13 Holman Hunt, 'The Lady of Shalott' reprinted in The Poetical Works of Alfred Tennyson

(New York: Harper Brothers, 1870) 


\section{LisT OF TABLES}

Table 4.1 Editions of Tennyson's poetry printed by Ticknor and Fields $1842-1858$

Table 4.2 Cumulative numbers of Tennyson's poems printed by Edward Moxon in Britain and Ticknor and Fields in the USA 